\title{
Paideusis
}

\section{William Hare, In Defence of Open-mindedness (Kingston and Montreal: McGill-Queen's University Press, 1985)}

\author{
C. M. Hamm
}

Volume 1, Number 1, 1987

URI: https://id.erudit.org/iderudit/1071145ar

DOI: https://doi.org/10.7202/1071145ar

See table of contents

Publisher(s)

Canadian Philosophy of Education Society

ISSN

0838-4517 (print)

1916-0348 (digital)

Explore this journal

Cite this review

Hamm, C. (1987). Review of [William Hare, In Defence of Open-mindedness (Kingston and Montreal: McGill-Queen's University Press, 1985)]. Paideusis, 1(1), 48-55. https://doi.org/10.7202/1071145ar viewed online.

https://apropos.erudit.org/en/users/policy-on-use/ 


\section{Book Review}

William Hare, In Defence of Open-mindedness (Kingston and Montreal: McGill-Queen's University Press, 1985)

Those who have had the opportunity of reading William Hare's other work, most notably his Open-mindedness and Education (1979), have come to expect rigorous conceptual analysis, precise argument, scholarly and thorough treatment of subject matter, relevance to education, clarity - in other words, good philosophy of education. His sequel, In Defence of Open-mindedness, maintains these standards though, as I shall point out, it is disappointing in some respects. Despite these problems, Open-mindedness has gold in it, even if one has to dig to find it. What we have another worthy contribution to philosophy of education.

His new book aims "to advance the study of open-mindedness. . . by showing what the attitude requires in a variety of contexts, and by demonstrating that it does not succumb to the many objections raised"(xii). As the title suggests, the book is a defence of open-mindedness in the context of education.

In the opening chapter, Hare sets the stage by defending openmindedness from a series of general attacks. He argues that any serious search for truth requires a presumption in favour of openmindedness, which is defined as "a willingness to form and revise one's views as impartially and objectively as possible in the light of available evidence and argument" $(3)$. Such an attitude commits one to comparing rival views. The first major objection to openmindedness is that such a comparison of rival views necessarily involves distortion. Open-mindedness is, after all, prejudicial since an impartial and objective assessment is impossible because in discussing an issue at all one rides rough-shod over the views of some. Opponents ofopen-mindedness say, for example, that comparison between the political systems of the U.S.A. and the U.S.S.R. begs the question about their equal value. Hare's argument to dismantle the objection is twofold. First, he says it is not true that issues discussed are necessarily distorted because one holds a particular view. Openmindedness requires only that one be fair to a view. It does not require that the view be supported. Second, those who claim that two views ought not to be compared and contrasted do themselves beg the question, for they also must compare and contrast to make the claim. In a similar manner, Hare defuses three other claims: that open-mindedness entails lack of commitment, entails lack of values, and neglects personal feelings. In each case, Hare denies the criticism 
and asserts the opposite, though I am not convinced that in each case he argues the counter claim.

My contention is that the major weakness in the book as a whole is Hare's frequent substitution of assertion and conceptual analysis for argument. For example, Hare is correct in noting that it is a mistake to confuse not being committed with not being committed in advance and in defiance of relevant evidence. Only the latter is required for open-mindedness. He thinks that clearing up that conceptual confusion is a sufficient counter-argument to those who claim that open-mindedness leads to lack of commitment. But the latter claim is not dismissed by conceptual clarification. A claim is defused by conceptual clarification only if it is held because of conceptual confusion. It is, in other words, possible not to be conceptually confused and still hold that open-minded people lack commitment. It is a question of fact whether or not they do. Conceptual analysis is not the appropriate response to claims of fact. An argument which cites evidence is required. Counter assertion is insufficient. This type of problem, I maintain, is repeated in a number of places in the book.

In Chapter 2, Hare defends open-mindedness by opposing those who argue that fostering an open-minded attitude and critical thought is an inappropriate goal for elementary school. In this connection, Hare opposes four types of objections: epistemological, logical, moral, and psychological. The epistemological objection, that elementary subject content is uncontroversial and, therefore, open-mindedness is inappropriate, is laid to rest by noting that uncontroversial material can be taught in a manner (roughly, discovery learning) of presenting evidence piecemeal. Just because evidence available does not mean it must be presented. Second, the logical objection is that the revision and alteration of views is logically possible only after some views are established. This is countered by the claim that students can be taught in such a way that they can begin to see views as tentative, held on the basis of evidence, and so the weight of evidence can shift. Open-mindedness, Hare argues, is willingness also to develop one's first ideas. Third, to the moral objection that children cannot grasp moral principles early on (the so-called paradox of moral education), Hare replies that teachers who stimulate children to develop through Kohlberg's stages are open-minded. "We can surely claim that teaching is open-minded which seeks to stimulate and promote the child's development through the stages"(21). Hare also recommends that teachers "keep the child's mind open to new ways of thinking about moral views"(21). In both of these replies, Hare's argument seems to me to be extremely weak. Does Hare really still believe in the stage theory of moral development? Has Kohlberg not virtually been demolished? But even granting the stage theory, where is the requirement that children "revise their views . 
- in the light of available evidence and argument" in order for them to develop through the stages, particularly stages one through four? And the suggestion that teachers keep children's minds open to new ways of thinking about moral issues surely begs the question. Because children are incapable of grasping moral principles, they are asked to keep an open mind to new ways of thinking on morals, a step which requires principles. One is reminded here of $R$. S. Peters' attempt to solve the empirical, practical problem of child-rearing by way of a conceptual distinction. 1 But a child's ignorance cannot be wished away by philosophers' ideals of rationality. Finally, in response to the psychological objection, that the timing of criticism is most effective overall if done when views are firmly established, Hare says that there is merit in the claim, but that it is not really an objection to open-mindedness. We should not try to make students more skeptical than we intend. The goal is to keep, or maintain, their minds as open, rather than attain openness in them for the first time.

In Chapter 3, Hare discusses the role of open-mindedness regarding moral principles, both with respect to the role of principles in moral life as well as in moral education. The challenge to openmindedness takes two forms. First, in practical contexts, rules sometimes need to be broken, but, since we do not know precisely when, it is better to stick to general rules in a closed-minded way. Second, it is not always clear when a general rule applies to a particular case, but, to avoid making exceptions to rules in your favour, no exceptions to rules should be allowed, again in a closed-minded way. Hare argues against these objections to open-mindedness by asserting that exceptions can be allowed without giving up principles, that exceptions do not entail wavering, corruptness, or unreliability of character, that open-mindedness does not entail uncertainty of obligation, nor exhaustive inspection of every situation, nor seeking out difficulties in our own views beyond a reasonable limit. In fact, Hare's whole argument seems to me to be one of appeal to reasonableness in ethical judgement, a positions with which no reasonable person would want to disagree. But, as noted with respect to Chapter One, there seems to be more assertion than argument here. What one would hope for here is an argument to show what is reasonableness in ethical judgement as demanded by open-mindedness. I shall address other problems with this chapter later.

In Chapter 4, Hare replies to those who feel that openmindedness threatens standards in education. He argues quite successfully that

open-mindedness does not require that we abandon attempts to defend standards. It requires that we will be 
willing to revise and reject standards if they fail to withstand scrutiny $(50)$.

He says further that "conceptual confusion lies behind the view that standards in education must eliminate open-mindedness in teaching'(51). To clear up these conceptual confusions, Hare notes that education requires both an attitude of open-mindedness and criticism and standards which makes achievement of educational goals intelligible. There is no contradiction in this. A view does not entail an inflexible view, predetermined goals do not entail closedmindedness, having objectives does not entail having specific, inflexible objectives, having standards does not entail having unreasonably high standards, assessing achievement of standards does not entail inadequate assessment and labelling of students, and so on. In this manner, the conceptual confusions are cleared up and openmindedness defended.

In Chapter 5, Hare challenges the alleged incompatibility between teaching and open-mindedness. It is said that teaching controls, channels, and curtails thinking and, hence, is closed-minded. Even stronger, the claim is that teaching rationality is incoherent. Teaching implies rational persuasion, but rational persuasion works only for the already rational. It is impossible for students to question the value of developing and using their rational capacities. The value of rationality can only be imposed, since it is impossible to be open-mindedness in teaching. Hare responds by showing that authority of the teacher does not entail authoritarianism, student deference does not entail passive acquiescence, and forced encountering of ideas does not entail forced acceptance of those ideas. In sum, education does not entail indoctrination. Rational teaching appeals to laws of logic which in principle cannot be questioned. Indoctrination fails to give reasons when it is vital to give them. Nothing in the concept of teaching, nor in the student-teacher relationship, rules out the possibility of open-mindedness.

In Chapter 6, Hare counters views which question the possibility of open-mindedness in administration. It would appear that certain requirements in administration such as decisiveness in rational decision-making, loyalty to the organization, and the need for consultation are at odds with open-mindedness. Not so, argues Hare. Open-mindedness is not incompatible with decisiveness. Openmindedness does not entail pointless or counter-productive consultation, promptness of decision, eschewing advice and counsel, or fencesitting. Loyalty does not entail unthinking loyalty. Hare makes the rather obvious observation that "we must be prepared to modify our organizational commitment if over-riding considerations arise"(66). With respect to the consultative process of administration, Hare observes that consultation does not entail having one's mind made up 
for one. Then, following a rather good analysis of what it means "to consult," he notes that consultation presupposes an open mind. Unless a person is willing to make revisions which are warranted, there is no genuine consultation. Confusion about open-mindedness leads it to being undervalued even in administration.

In Chapter 7, Hare defends the traditional view that openmindedness in science teaching is not a myth. This he does in the face of challenges by philosophers of science such as Kuhn who hold that "normal science," based on achievements in solving important problems which are probably familiar to us from our studies of science in high school, is "a closed society of closed minds." 2 Normal science works within a closed paradigm and cannot rationally appraise the merits of competing paradigms. "Extraordinary science," which replaces normal science in times of crises when anomalies and difficulties arise, it is argued, also is not amenable to openmindedness because the gestalt-like shift to a new paradigms. These gestalts are incompatible with evidence and argument required by open-mindedness. Thus the traditional view that science is the ideal example of open-minded study has recently been challenged. Hare faces and repels the challenge by arguing that open-mindedness can operate within a paradigm, that "there is no incompatibility between being guided by scientific achievement and willingness to consider the significance of anomalies"(78), that open-mindedness can check and test new paradigms to avoid serious anomalies (noting incidentally that gestalt switch applies to the psychology of the context of discovery, not to the justification of the findings), that competing paradigms can be rationally compared and judged and, finally, that assistance to change from within a paradigm is not necessarily closedminded. Defence of a theory can be conducted in a critical manner and ad hoc arrangements can indicate commitment which may be useful.

Open-mindedness is also possible and desirable in science education, Hare maintains. But what the argument is, I am not sure. It is buried in one of the most opaque and hasty passages in the entire book. I shall have reason to refer to it later.

In the final brief chapter. Hare shows that open-mindedness is not safe even from professed friends. He repeats the claim made in Chapter 1 that there is a strong presumption in favour of openmindedness for persons who want to arrive at true beliefs. But arriving at true beliefs is not advanced by censorship measures which intend to protect truth seekers against false beliefs. Rational appraisal, the hallmark of open-mindedness, is opposed to censorship. Liberal minded people often make other errors in the name of openmindedness, errors related to permissivism, neutrality, and wishywashiness. Hare shows that open-mindedness does not entail failure to make up one's mind, permissiveness, compromise, or indoctrination. 
I now turn to some observations about the book as a whole. I have already commented that frequently Hare asserts a counter position, but does not argue for it. But there is also much good argument, usually subtle and swift. For example, with respect to the position that authority is not incompatible with open-mindedness, he argues that rational authority derives from knowledge and claims to knowledge can be challenged. Corresponding student deference to the authority is compatible with open-mindedness for giving consideration to the views of teachers is implied by deference. Such consideration is necessary for open-mindedness for how else can one form or revise one's views? The argument, though terse, seems solid. However, immediately before this in response to the attack by radicals that hidden curriculum interferes with open-mindedness, Hare simply asserts that "students can be encouraged, directly and indirectly, to reflect on values and beliefs they are acquiring" $(58)$. What needs to be shown is how students can thus reflect on the values and beliefs when they are part of the hidden curriculum.

Sometimes the argument is just too obscure and allusions and references unexplained. Chapter 3, where Hare discusses the risks of being open-minded in ethics, is extremely difficult to follow (and there are numerous other passages in the book similarly difficult) because of gaps in the argument (and therefore non-sequiturs), lack of elaboration, obscure and unexplained references understandable only to the 'in' crowd, opaqueness, and obfuscation. Having studied (one doesn't read these things) the passage again and again, I am still not sure what the argument is and I do not think that readers' obtuseness is the entire problem.

Another extremely cryptic and obscure passage occurs in Chapter 7. Hare offers the following as an "important comment about science education which need(s) to be made in the context of openmindedness":

First, if we take the distinction between facts and methods of inquiry to parallel that between dogmatic and openminded science instruction, the importance of facts will make it impossible to defend an open-minded science approach. We can agree with Schwab in his condemnation of science teaching which amounts to "a nearly unmitigated rhetoric of conclusions." To teach a body of authoritative facts, however, is not at all the same as to impose a dogma in authoritarian fashion. In short, we need not worry if students "learn paradigms," but we must strenuously object if they are being encouraged to hold them in certain ways. (85)

After studying this passage, the reader still wants to know what 
exactly is the distinction between facts and methods of inquiry? What are examples of each? How is that distinction parallel to the distinction between dogmatic and open-minded? And is one who teaches enquiry necessarily open-minded? How so? What is the "importance of facts?" To whom? For what end? Just how does that importance make it impossible to defend an open-minded approach? What is Schwab's view in full? Why does Hare agree with him? What are authoritative facts? How do they differ from nonauthoritative ones? How can scientific facts become dogma? What is Hare's peculiar conception of "dogma" that allows this to be the case? What does it mean to learn a scientific paradigm? Why need we not worry if students learn them? Does Hare mean merely learn the paradigm without learning facts? Is that possible? Why must we strenuously object if students are being encouraged to hold them in certain ways? Which ways?

I do not want to over-emphasize the deficiencies in the book. There is no doubt that some philosophers will read and study the book and will be well rewarded. But my guess is that they will study it out of a sense of duty rather than for pleasure. However, I doubt whether other educators who should read the book will do so. One reason is that the book suffers from a defect common in philosophy: it is not very readable. By this I mean that the arguments, though mainly correct, are presented in a style that can only be described as cryptic and heavy. The book suffers from too few illustrations, too little elaboration, and too many vague and obscure allusions. It is too stolid and humourless. This is mainly a complaint about style. The otherwise rich content of the book is not affected. All the more is the pity that it is not more readable.

\section{M. Hamm \\ Simon Fraser University}

[EDITOR'S NOTE: William Hare will reply to this review in the next issue of Paideusis] 


\section{Notes}

${ }^{1}$ R. S. Peters, "Reason and Habit: The Paradox of Moral Education" in W. R. Niblett (Ed.), Moral Education in a Changing Society (London: Faber and Faber, 1963).

2 John Watkins, "Against Normal Science," in I. Lakatos \& A. Musgrave (Eds.), Criticism and Growth of Knowledge (Cambridge: Cambridge University Press, 1970), 27. 
sisit. 